\title{
Innovations in redevelopment projects
}

\author{
Dmitry Radushinsky ${ }^{2}$, Alexandra Radushinskaya $^{2}$, Ivan Radikov ${ }^{2}$ Oksana Feoktistova ${ }^{3}$ \\ and Andrey Butyrin ${ }^{4}$ \\ ${ }^{1}$ Institute for Entrepreneurship Problems LLC, 192241, 12-th line of Vassylievsky island, 11A, St. \\ Petersburg, Russia \\ ${ }^{2}$ St. Petersburg State University, 191104, Chaykovskogo 62, St. Petersburg, Russia \\ ${ }^{3}$ Moscow State Technical University of Civil Aviation, Kronshtadsky, 22, Moscow, 125009, Russia \\ ${ }^{4}$ Moscow State University of Civil Engineering, Yaroslavskoe shosse, 26, Moscow, 129337, Russia
}

\begin{abstract}
Some examples of redevelopment of industrial territories (lofting) abroad and in Russia for the purpose of qualitative research and classification, identification of the main features of process innovations are considered in the article. The following main parameters were established, according to which the differences in the implementation of various types of redevelopment projects were determined: the composition of the consumers of the services (the result) of the implemented project, the opportunities and the intensity of the flow of high-class specialists to the jobs created during the redevelopment of municipal and regional facilities, area, value (budget) and terms of project implementation. A perspective project of RTOs (museum-entertainment complex) for machine-building in Kolpino, as well as opportunities to expand the ecosystem of innovation Sochi Innovation Valley, was considered.
\end{abstract}

\section{Introduction}

The redevelopment of industrial territories contributes significantly to the stimulation of innovation activity at the regional and municipal levels, [1] which is also associated with the principle of "lofting" - the transformation of premises and spaces which previously had other function (mainly industrial) into the spaces of modern culture, education and business.

In the scientific literature, redevelopment issues have been considered quite widely, including the most promising technologies, such as complex landscaping of cities using led lamps [2]. Particularly noteworthy are the comprehensive works that reflect the experience and best practice of redevelopment in Europe and the US and the link with the aspects of the knowledge economy $[3,4]$. The stability of the transformation of the urban environment and its manageability were considered in the works $[5,6]$, the role of public spaces (multifunctional social spaces) in industrial loft development - in work [7]. A number of significant works reflect the experience of redevelopment in specific cities and regions: London [8], Chicago [9], Shenzhen, China [10], Detroit, USA [11], Cambridge [12],

\footnotetext{
${ }^{*}$ Corresponding author: angela-1309.m@yandex.ru
} 
Austin, Texas [13], New York, USA [14]. In [15], the role of media technologies for preserving the historical contexts of territories in the course of their redevelopment was explored.

The purpose of this work is to determine in what ways the process innovations [16] determine the specific forms of redevelopment, the set of user or consumers of the services (or other results) of the implemented project, the opportunities and the intensity of the flow of high-class specialists to the jobs created during the renovation / refurbishment and redevelopment municipal and regional facilities in the framework of the creation of multifunctional research and social spaces.

\section{Applied methodology, research materials}

A qualitative study was carried out, the main presupposition for which the authors consider the opportunity to identify the main features of process innovations and to characterize redevelopment projects for territories, for different purposes and budgets, depending on the type of redevelopment of the territory. The next goal was to establish the main consumers of services that are the result of lofting and redevelopment, using the examples of several implemented projects which could help to determine the boundaries of budgets and the timing of redevelopment projects.

In Europe and the USA, some of the most well-known loft development projects have been implemented, both at the local level of municipalities (small towns and individual territories within megacities) and the complex redevelopment of the territories of large cities and entire regions. In Russia, a number of projects have also been implemented or are being implemented.

Below we consider a set of examples of territories redevelopment projects for different purposes and of scale with the identification of the significance and main features of process innovations.

\subsection{Creation of an object of interest for mass tourism demand, with spaces for the creative class (level of municipal formation).}

As a landmark redevelopment project at the municipal level, the Museum of Autostadt in the city of Wolfsburg, Germany, the land of Lower Saxony is widely known. The city was founded in 1938 for the residence of employees of the then-established Volkswagen automobile concern, which were engaged in the creation of the Käfer (Beetle) car model. In Wolfsburg it is the very first factory and the headquarters of Volkswagen. The population of the city in the XXI century. - about 120 thousand people. The Autostadt Museum in Wolfsburg was built in 1998-2000 on the money that the Volkswagen concern saved on advertising companies during this period.

Autostadt is created as a complex place for leisure, cultural, entertainment and shopping complex. Against the backdrop of the industrial landscape, along the banks of the Mittelland Canal, a park zone, artificial ponds, walkways and multipurpose recreational facilities for adults and children have been created. A lot of money is invested in landscape design: birds are brought in, rabbits run around the lawns. Among the many buildings of the complex located on the territory of 28 hectares, there is an interactive museum of retro cars Zeithaus, which is a landmark, but not the main attraction center of the public. In numerous open and closed pavilions, regular exhibitions of contemporary art, auto shows, trainings are held regularly. The old Wolfsburg power station is turned into a fashionable "party" place, where the festival of modern dance Movimentos, exhibitions and other events takes place. On the territory of Autostadt are the famous towers for the storage of new cars Volkswagen - modern buildings with a height of 48 meters. 
As the notable process innovations in this example should be considered the several phenomena:

A) the direction of more than 1 billion (in euros) of the advertising budget, in other periods invested in television, on billboards and other traditional forms of advertisement of the automaker, in the creation of a theme park: the decision was taken by the head of the concern Ferdinand Piëch after visiting the American Disneyland;

B) application of spectacular landscape technologies - both traditional and new in content, combining in one territory the reconstructed areas of the object with new architectural and technical solutions and developments (towers for storing machines), creating spaces for exhibition and festival activities of modern German art and culture with an appeal to the representatives of the creative class.

As a result, a unique object appeared, connected primarily with the brand of the automaker, but also with the terrain that became more famous and attractive for tourists in Saxony.

Examples of redevelopment at the municipal level with the creation of unique imagebearing facilities for the area in Russia include the projects for the reconstruction of the New Holland complex in St. Petersburg under the project of the Dutch architectural bureau West 8 (2012-2019) and the construction of the Zaryadye park in the center of Moscow on the site of the former hotel "Russia" under the project of New York architects Diller Scofidio + Renfro and landscape designers Hargreaves Associates in common with Moscow urbanists Citymakers (2013-2017).

The area of the facility in St. Petersburg is about 4 times smaller (7.8 hectares) of the German "analog", and in Moscow - about 2 times (13 hectares). The project "New Holland", became an image for the company "Millhouse Capital" of Roman Abramovich, which act as investor, and the government of St. Petersburg. Creating of the park "Zaryadye" in Moscow was fully funded from the city budget.

The basic principles and some design redevelopment solutions used in Autostadt were repeated in Russian projects, with relevant modernization and adaptation of these solutions to the conditions of the facilities in the historical centers of the two Russian capitals.

Authors seen to be also promising the redevelopment project of the territory, presented in plan of strategic development of one of the indusrial satellite cities of St. Petersburg.

Scenarios for the strategic development of the city of Kolpino include the scenario of the city's development by 2025 as a major educational and innovative center in the field of metalworking and power engineering with a growing quality of life attractive to the life and work of skilled workers in industry and science.

On the basis of this scenario and the framework of the modern concept of territory branding (geo-branding), the city pretends to attract financing for the project which could be considered iconic for the image of municipal facility in St. Petersburg subagglomeration. This is the project of the MRK (museum-entertainment complex) of machine-building, demonstrating the achievements of nuclear engineering and the creation of multifunctional social spaces. Such a museum, like the one created by the Folkswagen Autostadt concern, could serve manufacturers of engineering products as an alternative channel for advertising their products, appealing to buyers while creating a game and communication zone that transforms the "depressed" urban area from an old-industrial function into a modern communicative and entertaining [17].

One of the most promising sites for the construction of such an object in Kolpino is part of the territory of the Izhorskiye Zavody OJSC, which is closest to the river Izhora bay, that is, in proximity to the popular local recreational zone and in the immediate vicinity of the administration of the city of Kolpino and the administration of Kolpinsky district of St. Petersburg. 
The creation of a museum and entertainment complex (MRK) in Kolpino should be in interested to the following set of subjects:

1. Investors carrying out strategic projects in the territory of famous Izhorskiye Zavody plant in Kolpino, according to the law of St. Petersburg "On strategic investment projects, strategic investors and strategic partners" dated December 3, 2008 N 742-136, holdings: "Power Machines" (PJSC Izhorskiye Zavody), Severstal (ZAO Severstal SMC-Kolpino, Izhorsky Pipe Plant, etc.), Magnitogorsk Iron and Steel Works (ZAO Interkos IV).

2. Other enterprises of machine building and metalworking of St. Petersburg, NorthWest Federal District, Russia as a whole. In this connection, we can speak, in particular, of Russian enterprises creating high-tech products in the field of nuclear energy and using nuclear technologies. In this line, expositions of enterprises - creators of space launch technologies and space exploration, as well as promising space and deep-water technologies - can be presented to attract the broadest sections of the public, including foreign tourists. Such an exhibition could provide tourists, arriving in St. Petersburg, the opportunity to get impressions of the peaceful technological achievements of the Russian Federation, echoing the exhibits of the Cosmonautics Museum at VDNH in Moscow.

3. Administration of St. Petersburg and the municipal formation (MO) Kolpino. The development of opportunities for the implementation of such a project in the framework of PPP, benefits and risks for the city administration in the event that this initiative was supported by investors could be an important contribution to its implementation, as well as an integral part of the program of measures to create an industrial and engineering cluster in Kolpino.

According to the plans of the administration of St. Petersburg, the transport accessibility of Kolpino will increase significantly by 2020 with the creation of a fast-track light rail line from the metro station "Shushary" ("Yuzhnaya"), which will open in 2018. The length of the high-speed tram network in Kolpino and Pushkinsky districts should be $13.5 \mathrm{~km}$. With the construction of an easy-rail tram line, as well as the unloading of the Moskovskoye highway, when the toll road "St. Petersburg - Moscow" is put into operation at the end of 2018, the transport accessibility of the Kolpino suburb for the population of St. Petersburg and tourists arriving in the city will increase significantly. The project of the MRK (museum-entertainment complex) of machine-building can become one of the attractive landmarks in the development of an accessible urban environment and creative spaces in the city of Saint-Petersburg in 2020s.

The possibility of growing a space for creative class in Kolpino will be facilitated by reaching agreements on the location of branches of Saint-Petersburg museums of contemporary art (for example, Erarta), the holding of music and art festivals, film screenings, etc. Creation of a gaming and entertainment zone in thematic styles for example, steampunk, which will correlate with the pro-production nature of the museumentertainment complex object, may be of interest to specialists developing urban projects for young people "Weavers", "Etazhi"," and others, developers of innovative audio-visual products - such as the manufacturer of navigation systems" Transas "(gaming complexes" Transforce ") and others.

\subsection{Creation of a scientific - industrial zone around the educational facility with the image of the space of intensive technical creativity (level of the region with access to the federal level).}

In a number of countries since the 1960s. the system of "production of services" developed, when the added value, represented by the share of services - largely managerial - in the GDP of these countries began to grow sharply against the background of deindustrialization. The emergence of programming as a branch of the mass application of 
labor, the spread of models of international business in which managerial, financial, insurance functions are realized on the territory of some countries, and the physical production of goods "taken to third countries" pushed the emergence of incentives for the knowledge economy and innovation - both technological and managerial, process as its main product.

"Scientific institutions of a new type that are developing the country with the direct assistance of business and authorities should become locomotives of modernization," Henry Itskowitz, author of the concept of the "triple helix" [18], described the "production of knowledge" system.

Ideon - the oldest and largest industrial park in Sweden, located in the south of the country in Lunde (Skåne province), its appearance is due to the idea and realities of the transition to the production of knowledge and management services. Traditional production, which previously specialized in the Swedish economy, suffered significant losses during the deindustrialization of Europe and against the backdrop of intensive economic development in a number of countries in South-East Asia. In the late 1970s and early 1980s, the shipyards in Malmö, the largest industrial enterprises in the eU Confederation, began to lose the market under the pressure of competitors from South Korea. Many of them were closed. The province faced massive unemployment.

In the early 1980 's. a team of young scientists from the University of Lund, one of the two largest universities in Sweden, led by Professor of Chemistry Svenom-Thor Holm, suggested that the university administration, the municipality of Lund and the governor of Skåne province build a technopark in the city that could help create new jobs in knowledgeintensive industries .

In September 1983, the foundation of the first building of the technopark was laid, and a few months later, its residents became the first two start-up pharmaceutical companies. By the beginning of 2010, over 30 years of development, Ideon had created more than 10 thousand jobs in science-intensive companies. There are 280 companies with 3 thousand employees. Only $15 \%$ of them specialize in consulting and service within the technopark. The rest are companies that implement projects in the field of communications and programming, pharmaceuticals, biotechnologies and "green" technologies.

The University played a decisive role in the development of both Lund and the Ideon Technopark: there are 40,000 students per 100,000 permanent residents of Lund [19].

Process innovation in this case should be considered as the following:

A) search and selection of the direction of further development, adapting the situation with unemployment in the region with high demands on the quality of labor resources, corresponding to the change in the focus of the qualification to the sphere of application of intellectual resources; creation of technologically oriented spaces for retention of the population with high professional potential;

B) the active role of representatives of the scientific community, who, according to the official portrait of the technopark, played the role of initiators, whose opinion was heard, and the developments were supported by government officials and strategic investors heads of large companies;

C) the special importance of the PR component of the project for the creation of a technopark that provided the inflow of new students - "techies" into the region with a high "industrial culture", contributed to reflection and the formation of ideas about further development in the knowledge economy, drawing attention to the "Scandinavian way" of implementation of innovations.

In Russia, a technopark is widely known in the Tomsk region, which arose in 1990 on the initiative of large Tomsk enterprises, banks, Tomsk State University of Control Systems and Radioelectronics and other universities, research institutes, administrations of the Tomsk region, Tomsk and Seversk. In 2010, Tomsk International Business Center 
"Technopark" took the 10th place in the rating of the most efficient university technoparks in Russia (based on accreditation results), while the 1st place was awarded to the International Science and Technology Park "Technopark in Moskvorechye" of Moscow State Engineering Physics Institute [20].

Residents of international technology parks are allocated with tax privileges and other advantages are given to them in doing business, as a result of which a number of technopark facilities in Russia were granted SEZ status - special economic zones. According to the results of 2017, the rating of the investment attractiveness of the special economic zones of Russia prepared by the Association of Clusters and Technoparks of the Russian Federation with the assistance of the Ministry of Economic Development headed the SEZ "Dubna", while the Tomsk SEZ was estimated as a facility with a moderate investment attractiveness for residents [21].

In "Dubna" three areas are distinguished: medical-pharmacological, nuclear-physical and nanotechnology, as well as a cluster in the field of information technology. With the participation of the company "PROMTEH-Dubna" the first tests "the main aircraft of the XXI century" - the passenger liner of the new generation MS-21, was successfully passed in May 2017

Technoparks in Russia in many respects accumulated during the period of its intensive development at the turn of 2000-2010. experience previously formalized by similar structures of the United States, Europe and the APR countries. However, process innovations in this area in the Russian Federation should be more closely correlated with the vector of reindustrialization (new industrialization) of the economy [22], which is implemented by some Russian enterprises, while a wide interconnection of companies resident in technoparks with teachers and students demonstrates a number of sites of technical universities. The main trend in the development of technology parks is the creation of new production zones in place of old industrial sites, which change their functional purpose.

High activity as residents of industrial parks in Russia is shown by manufacturers of auto components, pharmaceutical companies, petrochemical laboratories and other divisions of large resource and other industrial companies. It should be noted that the largest Russian IT companies (Yandex, Mail.ru, VKontakte and others) grew independently - in the market environment, outside the technology parks.

\subsection{Creation of a complex infrastructure in a large territorial formation to attract developing divisions of flagships of national and international scale (federal level).}

The city of Montpellier, the capital of the French Languedoc-Roussillon region in the late 1970s was famous for its excellent climate and a lot of wine. However, for thirty years Montpellier has acquired the status of a world-class high-tech center as a result of a consistent policy of supporting high-tech companies. Contribution of winemaking to the economy of the region today does not exceed $10 \%$, and more than $70 \%$ give high-tech industries - ICT, pharmaceuticals, "green" technologies.

Companies operating in Montpellier specialize in medical, information, agrotechnical and biotechnology, as well as on renewable energy, water resources management and their regeneration. The population of the city for the period 1980-2010. doubled, and unlike the rest of France it became younger - today $43 \%$ of the permanent residents of the agglomeration are younger than 30 years.

In the 1980-1990's. national PR campaign "Montpellier - a gifted city" to attract qualified and active people. Urban technologies were introduced in the city, including the development of easy-rail public transport (today the high-speed tram is the main means of 
transportation around the city), the creation of "smart" energy networks, a conference and concert hall was built, the second largest in the country after the Parisian Bercy. The Museum of Fabre was reconstructed, which made it the third most important museum in France.

In Montpellier there are three large universities - two natural sciences, including the oldest medical university in Europe, and one humanitarian.

The government paid attention to creating a "greenhouse" investment climate. The city has created a system of "soft landing" - a set of benefits and services that provide the most comfortable adaptation of foreign companies to local conditions and their access to the French and European markets. In the 2000s, Montpellier was repeatedly recognized as one of the most comfortable and cheap cities in Western Europe for opening and doing business. As a result, R \& D centers of such giants as IBM, Dell, Sanofi, Veolia, Ubisoft, Intel were deployed there, and more than 29,000 private enterprises operate here (about the same number in St. Petersburg for 5 million inhabitants).

Montpellier is confidently leading in France in terms of the number of start-ups that are created annually. Projects are placed in one of two technological business incubators CapAlfa and CapOmega, operated by the Center for Innovation Business (BIC), where a new enterprise is created and rises. Finally, the third stage, to which companies are moving at the growth stage, are technological parks. In Montpellier operates 18 business parks and two industrial parks specifically designed for graduates of business incubators.

All institutions of innovation support are the property of the regional administration (the Montpellier metropolitan area) and are under its direct management, and the specialists of business incubators BIC and technology parks are municipal employees by status.

Technopark Euromédecine Biopôle shelters projects in the field of medical and biotechnology, Millénaire - ICT projects. Technopark Biopôle that is six five-story buildings, located on the outskirts of the city. The construction of buildings allows to change the layout of laboratories depending on the wishes and possibilities of the resident company - here it is possible to rent the equipped premises with the area from 60 to several hundred square meters. Opened in 2011, the business incubator MIBI for foreign companies is called upon to attract quality innovative projects from all over the world in Montpellier [23].

The main features of process innovation in the case of Montpellier should be considered as follows:

A) The consistent multi-year policy of the French government and the authorities of the Montpellier region, which was aimed at attracting high-tech industries and research centers to a previously resort and wine region, with a hospitable mild climate (like Californian for Silicon Valley);

B) The national PR campaign "Montpellier - a gifted city" has been carried out for years to attract skilled and active people. This sort of professionals in the 2000s. have received a sustainable definition "creative class";

C) Introduction of new and promising town-planning technologies, which creates an additional visual and "kinesthetic" effect for visitors to the area.

A famous Russian case to "grow an ecosystem" of a high-tech region, such as Silicon Valley in the US and Montpellier in France, is the Skolkovo technopolis near Moscow. Of the many other regional projects, it makes sense to mention the Sochi Innovation Valley project.

The Skolkovo Innovation Center near Moscow is running by the Foundation for Development of the Center for the Research and Commercialization of New Technologies (Skolkovo Foundation) since 2010. In September 2010, a special federal law of the Russian Federation No. 244-FZ "On the Skolkovo Innovation Center" has been issued. In August of the same year, a Russian government decree regulating the visa regime for participants of 
the Skolkovo project was published, designed to soften the procedures for migration to Russia for foreign highly qualified specialists and members of their families. Residents of Skolkovo in 2018 are about 400 companies, of which 15 are international, including IBM. In the huge Russian innovation project, there is an attempt to apply most of the features implemented in Montpellier and Silicon Valley.

The significant infrastructural investments made in the Krasnodar Territory in connection with the preparations for the 2014 Winter Olympics and the milder climate of this region caused the emergence of the project of creating another large innovation zone in the region by the standards of Russia.

The Sochi Autonomous Non-Commercial Organization "The Sea of Ideas" has been promoting the Sochi Innovation Valley (SIV) project as a promising innovation ecosystem in the sphere of sports, gaming, medical, rehabilitation, recreational, tourist, agro- and biotechnologies since 2016. The expected performance indicators of the SIV (see Table 1 [24]) are quite ambitious, while in the current economic realities it is not like to await on large-scale state funding and support by special federal laws and regulations, unlike Skolkovo.

Table 1. Key indicators of the development of the Sochi Innovation Valley (SIV) under the development plan for the end of 2016.

\begin{tabular}{|l|c|c|c|c|c|}
\hline Indicator & 2017 & 2018 & 2019 & 2020 & 2021 \\
\hline $\begin{array}{l}\text { Number of companies - residents of SIV, } \\
\text { pcs. }\end{array}$ & 50 & 100 & 200 & 250 & 300 \\
\hline $\begin{array}{l}\text { The number of image (anchor) residents of } \\
\text { SIV (with an average of 50 employees } \\
\text { with a salary of 25 thousand rubles.), pcs. }\end{array}$ & 3 & 6 & 10 & 15 & 25 \\
\hline $\begin{array}{l}\text { Number of employees of companies - } \\
\text { residents of SIV and managing companies, } \\
\text { pers. }\end{array}$ & 293 & 550 & 1050 & 1300 & 1500 \\
\hline $\begin{array}{l}\text { The volume of investments attracted by } \\
\text { SIV residents (from the calculation of the } \\
\text { volume of investments attracted for the 1st } \\
\text { round, 7.5 million rubles), million rubles. }\end{array}$ & 150 & 300 & 600 & 750 & 900 \\
\hline
\end{tabular}

According to the parameters of the number of employees and companies, according to the international classification of technology parks, the SIV project when it reaches the set parameters will turn out to be medium, but not large, to which facilities with more than 5,000 employees belong.

When carrying out analogies with the Silicon Valley and Montpellier, the favorable climate of the Krasnodar Territory and the developed infrastructure of the city of Sochi within Russia give a potential incentive to deploy precisely this high-tech cluster location aimed at creating consumer innovations [25]. At the same time, the proximity to the state border and the limitation of the flat territory in the region not occupied by other objects (recreation, sports) are essential limitations for the prospects for the transformation of the SIV project into a large technopark. These factors, as well as restrictions on the state budget, are likely to be the reasons why the main areas of high-tech development in Russia in the near future will remain Skolkovo and the number of already established SEZ.

\section{Results}

Based on the results of a study of a complex of redevelopment projects for territories of different purposes and scale, a number of conclusions can be drawn, which are presented in Table 2. 
Table 2. Main results of qualitative research of a complex of redevelopment projects for territories of various purposes and scale

\begin{tabular}{|c|c|c|c|c|c|}
\hline $\begin{array}{c}\text { Type of } \\
\text { redevelopment of } \\
\text { the territory }\end{array}$ & $\begin{array}{c}\mathrm{S}, \\
\text { hectare } \\
\mathrm{s}\end{array}$ & $\begin{array}{c}\text { Main } \\
\text { consum } \\
\text { ers of } \\
\text { services }\end{array}$ & $\begin{array}{l}\text { The main features of process } \\
\text { innovation }\end{array}$ & $\begin{array}{l}\text { Budget, } \\
\text { terms } \\
\text { of } \\
\text { implem } \\
\text { entation }\end{array}$ & $\begin{array}{c}\text { Examples of } \\
\text { implementation }\end{array}$ \\
\hline 1 & 2 & 3 & 4 & 5 & 6 \\
\hline $\begin{array}{l}\text { I. Creation of an } \\
\text { object of interest in } \\
\text { mass tourism } \\
\text { demand, with spaces } \\
\text { for the creative class } \\
\text { (level of municipal } \\
\text { formation). }\end{array}$ & $5-30$ & $\begin{array}{l}\text { Tourists } \\
\text { parents, } \\
\text { intereste } \\
\mathrm{d} \text { in the } \\
\text { creative } \\
\text { develop } \\
\text { ment of } \\
\text { children } \\
\text { 'creative } \\
\text { class. }\end{array}$ & $\begin{array}{l}\text { 1. Opportunity for an individual investor } \\
\text { to invest his / her advertising / } \\
\text { sponsorship budget, which leads to the } \\
\text { formation / maintenance of a long-term } \\
\text { image / reputation of a large company. } \\
\text { 2. Application of spectacular landscape } \\
\text { technologies in combination with } \\
\text { architectural and technical solutions for } \\
\text { reconstruction and new construction on } \\
\text { the territory of the facility, creation of } \\
\text { spaces for cultural, exhibition and } \\
\text { festival, sports activities. } \\
\text { 3. Appeal to the representatives of the } \\
\text { creative class. }\end{array}$ & $\begin{array}{l}0.5-1.5 \\
\text { billion } \\
\text { dollars / } \\
\text { euro, 2- } \\
7 \text { years }\end{array}$ & $\begin{array}{l}\text { Autostadt (Germany), } \\
\text { Zaryadye Park (Moscow), } \\
\text { New Holland, project of } \\
\text { MRK in Kolpino (St. } \\
\text { Peters-burg) }\end{array}$ \\
\hline $\begin{array}{l}\text { II. Creation of a } \\
\text { scientific - industrial } \\
\text { zone around the } \\
\text { educational facility } \\
\text { with the image of } \\
\text { the space of } \\
\text { intensive technical } \\
\text { creativity (level of } \\
\text { the region with } \\
\text { access to the federal } \\
\text { level). }\end{array}$ & $25-100$ & $\begin{array}{l}\text { Workers } \\
\text { of the } \\
\text { establish } \\
\text { ed } \\
\text { Indian- } \\
\text { tral } \\
\text { zone, } \\
\text { abi- } \\
\text { tourists } \\
\text { and } \\
\text { students } \\
\text { workers } \\
\text { - } \\
\text { ians", } \\
\text { ready to } \\
\text { move }\end{array}$ & $\begin{array}{l}\text { 1. Creation of technologically oriented } \\
\text { spaces for retaining of a population with } \\
\text { high professional potential, with a } \\
\text { possible change in the focus of the } \\
\text { qualification on the background of a shift } \\
\text { in the industrial zone of specialization. } \\
\text { 2. The active role of the representatives } \\
\text { of the scientific and expert community } \\
\text { who, in accordance with the concept of } \\
\text { the "triple helix", can initiate the project } \\
\text { and in the future conceptually participate } \\
\text { in the development of the project when } \\
\text { obtaining an agreed technical assignment } \\
\text { from government officials and strategic } \\
\text { investors - the management of large } \\
\text { private or state companies } \\
\text { 3. The high value of the PR-component, } \\
\text { aimed at ensuring the inflow of students } \\
\text { and workers of technical specialties into } \\
\text { the region with a high "industrial culture" } \\
\text {.. }\end{array}$ & $\begin{array}{l}0,2-2 \\
\text { billion } \\
\text { dollars / } \\
\text { euro, 1- } \\
7 \text { years }\end{array}$ & $\begin{array}{l}\text { Ideon (Lunde, Sweden); } \\
\text { MDC "Technopark" } \\
\text { (Tomsk), SEZ "Dubna" } \\
\text { (Moscow region), } \\
\text { technoparks of various } \\
\text { specializations of medium } \\
\text { size }\end{array}$ \\
\hline $\begin{array}{l}\text { III. Creation of an } \\
\text { integrated } \\
\text { infrastructure in a } \\
\text { large territorial } \\
\text { formation to attract } \\
\text { the developing } \\
\text { divisions of the } \\
\text { flagship companies } \\
\text { of national and } \\
\text { international scale } \\
\text { (federal level). }\end{array}$ & $\begin{array}{l}30-100 \\
\text { and } \\
\text { more }\end{array}$ & $\begin{array}{l}\text { Compan } \\
\text { ies } \\
\text { intereste } \\
\mathrm{d} \text { in the } \\
\text { results } \\
\text { of } \\
\text { fundame } \\
\text { ntal and } \\
\text { applied } \\
\text { research } \\
\text { develop } \\
\text { ment of } \\
\text { innovati } \\
\text { ons }\end{array}$ & $\begin{array}{l}\text { 1. Consistent multi-year government } \\
\text { policy at the federal and regional level } \\
\text { aimed at attracting high-tech industries } \\
\text { and research centers to the selected } \\
\text { region, characterized, as a rule, by a mild } \\
\text { mild climate; } \\
\text { 2. Conducting a national PR campaign to } \\
\text { attract qualified and active people, } \\
\text { including unique domestic and foreign } \\
\text { scientists, specialists and managers, } \\
\text { attracted by the possibility of cooperation } \\
\text { between representatives of the "creative } \\
\text { class" and qualified middle managers; } \\
\text { 3. Introduction of new and promising } \\
\text { town-planning technologies, which } \\
\text { creates an additional visual and } \\
\text { "kinesthetic" effect for the visitors of the } \\
\text { area }\end{array}$ & $\begin{array}{l}\text { From \$ } \\
5 \\
\text { billion, } \\
\text { includin } \\
\mathrm{g} \\
\text { commun } \\
\text { al and } \\
\text { road } \\
\text { infrastru } \\
\text { cture. } \\
\text { From 5 } \\
\text { years }\end{array}$ & $\begin{array}{l}\text { Montpellier (France), } \\
\text { Silicon Valley (USA), } \\
\text { Skolkovo (Moscow } \\
\text { region), Sochi Innovation } \\
\text { Valley (project) }\end{array}$ \\
\hline
\end{tabular}

Source: compiled by the authors 


\section{Conclusion}

According to the data presented in Table 2, the work establishes a classification and defines the main features of process innovations during the implementation of various types of redevelopment projects, the set of users / consumers of the services (result) of the implemented project, the opportunities and the intensity of the flow of high-class specialists to jobs created during the redevelopment of municipal and regional facilities.

The results of the work can be used as an analytical base by municipal and regional authorities when formulating plans for strategic development of territories, as well as programs for supporting local innovative initiatives. Also, the information presented may be of interest to specialized territorial units (agencies) of innovation development, regional centers of public-private partnerships, specialists from innovation centers of large companies, interested experts.

The key direction of further research is the thorough research with the identification of features and the consideration of "best practices" in the examples of redevelopment in the territories of Japan and China, other countries of the Asia-Pacific region and BRICS, which are poorly illustrated in the literature, as well as a comprehensive assessment of the efficiency of redevelopment of municipal and regional sites in the framework of the creation of multifunctional research and social spaces.

\section{References}

1. M. Basnukaeva, A. Shlafman, Redevelopment industrial'nykh territoriy (St. Petersburg: Kult-inform-press, 2013).

2. S. Connop et al. Environmental Science \& Policy 62, 99-111 (2016)

3. S. Pancholi, T. Yigitcanlar, M. Guaralda, International Journal of Knowledge-Based Development (IJKBD), 6-3 (2015)

4. B. Hersh. Urban Redevelopment (A North American Reader, Routledge, 2018)

5. L.Ernst, et al., Journal of Cleaner Production, 112-4, 2988-2999 (2016)

6. N. Frantzeskaki, N. Kabisch, T. McPhearson, Environmental Science \& Policy, 62, 1144 (2016).

7. A. Mottaeva, A. Zheltenkov E3S Web of Conferences, 3301038 (2018)

8. C. Hamnett, D. Whitelegg., Environment and Planning A: Economy and Space, 39-1, 106-124 (2007)

9. E. Vasilyeva, A. Zlentenkov, O. Suzneva, E. Sapozhnikova, IOP (Earth and Environmental Science), 90 (1) 12122 (2017)

10. W. Jung, K. Wanjing, Ch. Wang, X. Liu, Land Use Policy, 69, 307-316 (2017)

11. J. Ross, Spaces \& Flows: An International Journal of Urban \& Extra Urban Studies, 74, 35-48 (2016)

12. E. Vasilyeva, T. Sazonova, IOP (Earth and Environmental Science), 90 (1), 012116 (2017)

13. J. Heathcott. City, 19- 1, 79-100 (2015)

14. A. Antonova, A. Radushinskaya, O. Sharapova, Services in Russia and abroad, 11 (77), 17-32 (2017)

15. T. Meshcheriakova, Applied and Fundamental Studies, 2, 186-188 (2018)

16. D. Radushinsky, St. Petersburg Economic Journal, 2, 40-48 (2015) 
17. R. Viale, H. Etzkowitz. The Capitalization of Knowledge: A Triple Helix of University-Industry-Government (Cheltenham, Glos, UK: Edward Elgar, 2010)

18. A. Seleznev, A. Mottaeva, L. Andreeva, S. Izmaylova, IOP Conference Series: Earth and Environmental Science, 90 (1), 012117 (2017)

19. D. Mindich, Expert. Vol. 35, 58 - 62 (2011).

20. M. A. Bahauovna, M. A. Bahauovna, International Journal of Applied Engineering Research, 10 (23), 43446-43449 (2015)

21. M. A. Bahauovna, M. A. Bahauovna, International Journal of Applied Engineering Research, 11 (9), 6808-6816 (2016)

22. E. Vasilyeva, and V. Okrepilov E3S Web of Conferences 3303048 (2018)

23. Mindich D. Well-born innovations, Expert, 41 (2011).

24. A. Mottaeva, MATEC Web of Conferences, 106, 08072 (2017)

25. E. Gumerova, O. Gamayunova, T. Meshcheryakova, Advances in Intelligent Systems and Computing, 692, 432-439 (2018) 